\title{
Studies on Acceptability, Chemical Composition and Cost Structure of Kheer Prepared from Cow Milk Blended with Coconut Milk
}

\author{
S.R. Barela* and R.R. Shelke \\ Department of Animal Husbandry and Dairy Science, Dr. P.D.K.V., Akola - 444104 (MS), India \\ *Corresponding author
}

\begin{tabular}{|c|c|}
\hline & A B S T R A C T \\
\hline $\begin{array}{l}\text { Ke e y w o r d s } \\
\text { Blending, Coconut } \\
\text { milk, Cow milk, } \\
\text { Kheer, Sensory } \\
\text { evaluation, Chemical } \\
\text { composition, Cost of } \\
\text { production. }\end{array}$ & \multirow{3}{*}{$\begin{array}{l}\text { The present investigation on "Studies on Acceptability, Chemical Composition and Cost } \\
\text { Structure of Kheer Prepared from Cow milk Blended with Coconut milk" was undertaken } \\
\text { with a view to utilize valuable, nutritious coconut milk with cow milk for preparation of } \\
\text { kheer and to obtained value added product. The cow milk was blended with coconut milk } \\
\text { in the proportion of } 100: 00\left(\mathrm{~T}_{1}\right), 90: 10\left(\mathrm{~T}_{2}\right), 80: 20\left(\mathrm{~T}_{3}\right), 70: 30\left(\mathrm{~T}_{4}\right) \text {, and } 60: 40\left(\mathrm{~T}_{5}\right) \text { for } \\
\text { preparation of kheer. It was observed that overall acceptability of kheer prepared from cow } \\
\text { milk blended with coconut milk in proportion } 80: 20 \text { found superior while for } 90: 10,70: 30 \\
\text { and } 60: 40 \text { had fair quality. Regarding chemical quality fat and total solid content of } \\
\text { product increased significantly while protein content decreased significantly with increases } \\
\text { in the rate of addition of coconut milk. It was also observed that increase in the level of } \\
\text { coconut milk blending significantly increase the cost of production of kheer. Hence from } \\
\text { present investigation it can be concluded that blending of } 20 \text { per cent coconut milk with } 80 \\
\text { per cent cow milk was useful for manufacture of kheer. }\end{array}$} \\
\hline Article Info & \\
\hline $\begin{array}{l}\text { Accepted: } \\
\text { 20 September } 2017 \\
\text { Available Online: } \\
\text { 10 November } 2017\end{array}$ & \\
\hline
\end{tabular}

\section{Introduction}

A sweetened dish of rice cooked in milk first finds mention as 'Payasa' in Buddhist-Jain literature in 400 B.C. Payasam is milk based delicacy popular in the southern parts of India. It resembles kheer of North India and has similar ritualistic connotations. Kheer from jowar is mentioned in the fourteenth century 'Padmavat' of Gujarat. Today, other cereals and cereal products (Vermiceli, Sevian, Phirni) are also used in kheer preparations.

The importance of milk and milk products in India is realized since vedic period. It supplies various nutrients like milk fat, protein, vitamin $\mathrm{A}$ and lactose. Milk has been described as most ideal food which referred as "Bank of Nutrients". Coconut milk has developed considerable interest in nutrition as it could be one of the possible substitutes for milk at reasonable cost. It is considered very healthy in Ayurveda. Some people believe that coconut milk can be used as a laxative. It is also used for healing mouth ulcers. Coconut milk has a medicinal and therapeutic value. It stimulates growth. It is highly digestible and found quite effective in curing gastric troubles. It is useful for feeding infants and children. It is highly energetic food and a tonic for persons suffering from diabetes, blood pressure, kidney troubles, general weakness and diseases related to malnutrition 
in children and pregnant women. It also acts as an effective brain tonic (Hogemmaier, 1980).

Coconut has been utilized as milk substitute in the preparation of variety of milk products. This indicates that there is tremendous scope of milk product prepared from coconut which increases nutritive value for product at cheaper rate. Mostly ghee is used for smoothness and richness of kheer, which can also subtracted by coconut milk (Pszczola 2001).

\section{Materials and Methods}

The present research work was undertaken in the Department of Animal Husbandry and Dairy Science, Dr. Panjabrao Deshmukh Krishi Vidyapeeth, Akola. The procedures adopted for experimentation in the present study are given below.

\section{Procurement of milk and ingredients}

Fresh cow milk was procured from the Livestock Instructional Farm, Department of Animal Husbandry and Dairying, Dr. P.D.K.V. Akola. Ingredients like sugar, rice (Basmati) and coconut was purchased from the local market.

\section{Preparation of coconut milk}

First black skin of wet coconut fruit was taken out, followed by grating of coconut. A small quantity of water was added in grated coconut and it was allowed to soak for 20 minutes. Water soaked grated coconut was blended into mixer for one minute. Finally, the entire mixture was squeezed and was strain through the muslin cloth. The coconut milk so prepared was used in different combinations with cow milk for kheer preparation. For obtaining $250-300 \mathrm{ml}$ coconut milk one wet coconut $(480+4 \mathrm{~g})$ was required.

\section{Details of treatments}

Cow milk was blended with coconut milk as $\mathrm{T}_{1}$ (100:00), $\mathrm{T}_{2}$ (90:10), $\mathrm{T}_{3}$ (80:20), $\mathrm{T}_{4}$ (70:30) and $\mathrm{T}_{5}(60: 40)$ all five treatments were replicated for five times.

\section{Preparation of kheer}

Kheer was prepared with different proportion of cow milk and coconut milk as suggested by De (2009).

\section{Analytical Methods}

\section{Sensory evaluation}

The samples of fresh product were subjected to organoleptic evaluation to judge the acceptability of product by panel of judges as per method suggested by Dharam Pal and Gupta (1985).

\section{Analysis of kheer}

Fat content of kheer was determined by using Soxhlets extraction method as per the procedure recommended in A.O.A.C. (1990).

Protein content in kheer was determined as per the procedure recommended in B.I.S. Handbook of food analysis dairy products IS: 1166 (1973).

Ash content in kheer was determined by IS: 1165 (1967). The percentage of total solids in kheer was determined by using gravimetric method as per the procedure of B.I.S. Handbook of Food Analysis, IS: 1166 (1973).

\section{Cost of production}

Cost of production of kheer was calculated by considering the prevailing rates of raw material, labour charges, gas, electricity and other miscellaneous charges, etc. 


\section{Statistical analysis}

The data obtained was statistically analyzed by Randomized Block Design (RBD) as per the procedure prescribed by Amble1975.

\section{Results and Discussion}

\section{Sensory evaluation of kheer}

In order to evaluate a good quality kheer the panel of judges was selected and product was judged with the help of score cards and data generated were statistically processed and the results obtained are presented in the Table 1.

\section{Colour and appearance}

It was observed from Table 1 that, highest colour and appearance score was obtained in treatment $\mathrm{T}_{3}$ (19.64) while lowest in treatment $\mathrm{T}_{5}$ (14.54). Kheer prepared from 80 per cent cow milk blended with 20 per cent coconut milk $\left(\mathrm{T}_{3}\right)$ was significantly superior over the $\mathrm{T}_{1}, \mathrm{~T}_{2}, \mathrm{~T}_{4}$ and $\mathrm{T}_{5}$.

Colour and appearance of cow milk blended with coconut milk kheer was light brownish in colour. The results obtained in present investigation were in agreement with Unnikrishnan et al., (2000). The colour of the payasam varied from white, light cream, cream and light brown to brown.

\section{Flavour of kheer}

The results indicated that the kheer prepared from $\mathrm{T}_{3}$ level recorded highest score for flavour (43.20) followed by $\mathrm{T}_{2}$ (40.94), $\mathrm{T}_{1}$ (39.50), $\mathrm{T}_{4}$ (37.80) and lowest in $\mathrm{T}_{5}(36.38)$. The sensory score increased up to $\mathrm{T}_{3}$ i.e. 20 per cent level of coconut milk and decreased simultaneously for $T_{4}$ and $T_{5}$. Lowest score was noticed for kheer prepared from 60 per cent cow milk blended with 40 per cent coconut milk $\left(\mathrm{T}_{5}\right)$.

\section{Body and texture of kheer}

The kheer prepared from $T_{3}$ level recorded highest score for body and texture (34.67) followed by $\mathrm{T}_{2}$ (33.94). The sensory score increased up to $\mathrm{T}_{3}$ i.e. 20 per cent level of coconut milk and decreased simultaneously for $\mathrm{T}_{4}$ and $\mathrm{T}_{5}$. Lowest score was noticed for kheer prepared from 60 per cent cow milk blended with 40 per cent coconut milk. The cow milk kheer was thick and have compact body. This might be due to gel consistency of rice while coconut milk kheer was having maximum smoothness as compare to kheer prepared from cow milk.

\section{Overall acceptability}

From average figures of overall acceptability, it was clear that kheer prepared from 80 per cent cow milk and 20 per cent coconut milk scored highest point (97.14), followed by 10 per cent coconut milk and 90 per cent cow milk in kheer (93.46). The score simultaneously declined as $87.84,84.58$ and 78.32 for $\mathrm{T}_{1}, \mathrm{~T}_{4}$ and $\mathrm{T}_{5}$, respectively.

\section{Chemical analysis of kheer}

The results in respect of chemical analysis of kheer blended with different level of coconut milk are tabulated in Table 2.

\section{Fat}

The perusal of data from Table 2, it was observed that blending of coconut milk increased the fat content of kheer can be attributed to the fact that the fat content of coconut milk is higher than that of cow milk (i.e. 40.00 and 4.6 per cent respectively) there was significant $(\mathrm{P}<0.05)$ effect of proportion of cow milk and coconut milk on fat content in kheer. The average fat content of kheer was $7.69\left(\mathrm{~T}_{1}\right), 7.95\left(\mathrm{~T}_{2}\right), 9.83\left(\mathrm{~T}_{3}\right), 10.94\left(\mathrm{~T}_{4}\right)$ and $11.75\left(\mathrm{~T}_{5}\right)$. 
Table.1 Sensory evaluation of kheer prepared from cow milk blended with coconut milk

\begin{tabular}{|c|c|c|c|c|}
\hline \multirow{2}{*}{$\begin{array}{c}\text { Treatments } \\
(\mathbf{c m : c c m})\end{array}$} & \multicolumn{3}{|c|}{ Mean values of scores obtained for five replications (Score/Marks) } \\
\cline { 2 - 5 } & $\begin{array}{c}\text { Colour and } \\
\text { Appearance } \\
(\mathbf{2 0})\end{array}$ & $\begin{array}{c}\text { Flavour } \\
\mathbf{( 4 5 )}\end{array}$ & $\begin{array}{c}\text { Body and texture } \\
\mathbf{( 3 5 )}\end{array}$ & $\begin{array}{c}\text { Overall } \\
\text { acceptability } \\
(\mathbf{1 0 0})\end{array}$ \\
\hline $\mathrm{T}_{1}(100: 00)$ & 16.56 & 39.50 & 32.20 & 87.84 \\
\hline $\mathrm{T}_{2}(90: 10)$ & $18.42^{*}$ & $40.94^{*}$ & $33.94^{*}$ & $93.46^{*}$ \\
\hline $\mathrm{T}_{3}(80: 20)$ & $19.64^{*}$ & $43.20^{*}$ & $34.67^{*}$ & $97.14^{*}$ \\
\hline $\mathrm{T}_{4}(70: 30)$ & 15.48 & 37.80 & 31.52 & 84.58 \\
\hline $\mathrm{T}_{5}(60: 40)$ & 14.54 & 36.38 & 27.56 & 78.32 \\
\hline${ }^{\prime} \mathrm{F}^{\prime}$ test & Sig. & Sig. & Sig. & Sig. \\
\hline $\mathrm{SE}(\mathrm{m})+/-$ & 0.142 & 0.564 & 1.016 & 1.054 \\
\hline $\mathrm{CD}$ at $5 \%$ & 0.428 & 1.693 & 3.046 & 3.161 \\
\hline
\end{tabular}

(cm cow milk, ccm coconut milk, $* \mathrm{P}<0.05)$

Table.2 Effect of cow milk blended with coconut milk on chemical composition of kheer

\begin{tabular}{|l|c|c|c|c|}
\hline \multirow{2}{*}{$\begin{array}{c}\text { Treatments } \\
\text { Cow milk: } \\
\text { Coconut milk) }\end{array}$} & \multicolumn{4}{|c|}{ Mean values of five replications in per cent } \\
\cline { 2 - 5 } & & Protein & Total Solids & Ash \\
\hline $\mathrm{T}_{1}(100: 00)$ & 7.69 & $7.22^{*}$ & 30.448 & 1.288 \\
\hline $\mathrm{T}_{2}(90: 10)$ & 7.95 & 7.11 & 33.088 & 1.664 \\
\hline $\mathrm{T}_{3}(80: 20)$ & 9.83 & 7.05 & 37.414 & 1.872 \\
\hline $\mathrm{T}_{4}(70: 30)$ & 10.94 & 6.90 & 40.840 & 2.094 \\
\hline $\mathrm{T}_{5}(60: 40)$ & $11.75^{*}$ & 6.84 & $45.122^{*}$ & $2.382^{*}$ \\
\hline${ }^{*} \mathrm{~F}$ ' Test & Sig. & Sig. & Sig. & Sig. \\
\hline SE $(\mathrm{m})+/-$ & 0.028 & 0.010 & 0.021 & 0.041 \\
\hline $\mathrm{CD}$ at $5 \%$ & 0.085 & 0.032 & 0.064 & 0.124 \\
\hline
\end{tabular}

Table.3 Cost of per kg kheer production (based on cost of ingredients)

\begin{tabular}{|l|c|c|c|c|c|c|}
\hline \multirow{2}{*}{ Ingredients } & \multirow{2}{*}{ Rate (Rs.) } & \multicolumn{5}{c|}{ Treatments cost (Rs.) } \\
\cline { 3 - 7 } & & $\mathbf{T}_{\mathbf{1}}$ & $\mathbf{T}_{\mathbf{2}}$ & $\mathbf{T}_{\mathbf{3}}$ & $\mathbf{T}_{\mathbf{4}}$ & $\mathbf{T}_{\mathbf{5}}$ \\
\hline Cow Milk (Rs./Lit.) & 20 & 20.00 & 18.00 & 16.00 & 14.00 & 12.00 \\
\hline Coconut Milk (Rs./Lit.) & 70 & -- & 7.00 & 14.00 & 21.00 & 28.00 \\
\hline Basmati Rice (Rs./Kg.) & 50 & 12.50 & 12.50 & 12.50 & 12.50 & 12.50 \\
\hline Sugar (Rs./kg.) & 30 & 7.50 & 7.50 & 7.50 & 7.50 & 7.50 \\
\hline Ghee (Rs./Kg.) & 350 & 11 & 11 & 11 & 11 & 11 \\
\hline Cost of Ingredients & -- & 51.00 & 56.00 & 61.00 & 66.00 & 71.00 \\
\hline Fuel Charge @ 355/14 kg. & 355 & 9.12 & 9.12 & 9.12 & 9.12 & 9.12 \\
\hline Total Cost of kheer/kg. & -- & 60.12 & 65.12 & 70.12 & 75.12 & 80.12 \\
\hline
\end{tabular}

The perusal of data from Table 3 it was observed that increase in the level of coconut milk blending with cow milk resulted in increase in the cost of production of kheer.

The present findings were supported by the observations of Mathur et al., (1985) who reported that Phirni was prepared from milk with varying fat. The Phirni was prepared by using skim milk (0.1\% fat) milk standardized to 3.5 per cent fat, milk standardized to 5.0 
per cent fat and high fat milk with 6.5 per cent fat. In all the cases, the SNF content of the milk was higher than 9.0 per cent.

\section{Protein}

The perusal of data from Table 2, it was observed that blending of coconut milk showed gradual decrease in protein content of kheer. The highest protein content in kheer (7.22 per cent) was observed in treatment $\left(\mathrm{T}_{1}\right)$ i.e. kheer prepared from cow milk without coconut milk and the lowest (6.84 per cent) at 40 per cent level of coconut milk $\left(\mathrm{T}_{5}\right)$. The present findings were supported by the observations of Mathur et al., (1985).

\section{Ash}

The ash content of kheer increased with the increase in the level of coconut milk. The highest ash content in kheer (2.382 per cent) was observed in treatment $\left(\mathrm{T}_{5}\right)$ at 40 per cent level of coconut milk and lowest (1.288 per cent) from cow milk without coconut milk. The findings of De et al., (1974) were supportive to present trend where they observed 1.41 per cent ash, in kheer. Sankhla et al., (1990) also reported that the ash content in kheer was 1.40 per cent and Jha (2000), who observed that the ash content in kheer mix was 2.64 per cent.

\section{Total solids}

It was observed that total solids content showed gradual increase with the increase in level of coconut milk. The lowest total solids content was noticed at $\left(\mathrm{T}_{1}\right)$ i.e. kheer prepared from cow milk without coconut milk (30.448 per cent). While, the highest total solids content was observed at $\left(\mathrm{T}_{5}\right)$ i.e. kheer prepared from 60 per cent cow milk with 40 per cent coconut milk (45.122 per cent). Similar type of observations was recorded by other scientists. Mani et al., (1955) reported
31.0 per cent total solids in kheer. De et al., (1974) noticed 37.37 per cent total solids in kheer. De (1980) reported 32.98 per cent total solids in kheer. The total solids percentage mainly depends upon the fat percentage, ratio of concentration and addition of sugar and rice percentage. The increase in fat increases the total solids and increase in the degree of concentration increases the total solids percentage.

\section{Cost of production}

Data pertained to the cost of production of kheer prepared from cow milk blended with different level of coconut milk is tabulated in Table 3.

The most acceptable quality of kheer can be prepared from 80 per cent cow milk blended with 20 per cent coconut milk. Use of coconut milk more than 20 per cent level blending in cow milk for preparation of kheer adversely affect the acceptability. Fat and total solid content of product increased significantly while protein content decreased significantly due to addition of coconut milk proportion, increased from 10 to 40 per cent. The cost of kheer was increased with increase in the levels of blending of coconut milk in cow milk. Hence it may be concluded that coconut milk could be successfully utilized for the preparation of kheer.

\section{References}

A.O.A.C. 1990. Official Methods of Analysis $\left(15^{\text {th }}\right.$ Edn.). Association of Official Analytical Chemist, Washington, D. C.

Amble, V.N. 1975. Statistical Method in Animal Sciences. 191-195.

De Sukumar, Dilip Thompkinson., Dharampal and Mathur, O.N. 1974. Studies on the canning of kheer with or without additive. Annual Report, N. D.R.I., Karnal, p." 187. 
De, S. 1980 and ED 2009. Outlines of Dairy Technology. Oxford University Press. New Delhi, India, 6-20.

Dharampal and Gupta, S.K. 1985. Sensory evaluation of Indian milk products. Indian Dairyman. 37-47.

Hogemmaier. 1980. Cited in coconut milk. Indian coconut J. 25 (5): 2-13.

IS : 1165. 1967. Specification for condensed milk. Indian Standard Institution, ManakBhawan, 9, BahadurShah Zafar Marg, New Delhi.

IS : 1166. 1973. The specification of full cream sweetened condensed milk. Indian Standard Institution, Manak Bhawan, 9, Bahadur Shah Zafar Marg, New Delhi.

Jha, A. 2000. Development of process for long life Kheer and instant Kheer and instant kheer mix. Ph.D. Thesis N.D.R.I. Deemed University, Karnal.

Mathur O.N. Bhattacharrya D.C. and Roy N.K. 1985. Phirni and Indian sweet dish. Indian Dairyman. 37 (12): 575578.

Pszezola, D.E. 2001. Antioxidants: from preserving food quality to quality of life. Food Tech. 55 (6): 55-59.

Sankhla, A.K., Sankhale, Aarti., Yadav, R.K.; Rao, D.V. and Bhatnagar, Sanjeev. 1990. Kheech: An indigenous milk product of Rajasthan. Indian Dairyman. 42 (1): 15-16.

Unnikrishnan. V., Bhavadasan, M.K., Nath. B.S., Vedavathi, M.K. and Balasubramanya, N.N. 2000. Payasam and sweet delicacy. Indian Dairyman. 52 (10): 37-42.

\section{How to cite this article:}

Barela, S.R. and Shelke, R.R. 2017. Studies on Acceptability, Chemical Composition and Cost Structure of Kheer Prepared from Cow Milk Blended with Coconut Milk. Int.J.Curr.Microbiol.App.Sci. 6(11): 2527-2532. doi: https://doi.org/10.20546/ijcmas.2017.611.297 